\title{
Putative steroid-binding receptors and nonreceptor components and testicular activity in the lizard Podarcis sicula sicula
}

\author{
M. Paolucci and M. M. Di Fiore \\ Dipartimento di Zoologia, Università di Napoli, Via Mezzocannone, 8, 80134 Napoli, Italy
}

\begin{abstract}
Summary. Labelled testosterone- and oestradiol-binding molecules have been found in the cytosol and nuclei of lizard testes. DNA-cellulose affinity chromatography was used to separate putative sex-steroid-binding receptors (adhering molecules) and nonreceptor components (nonadhering molecules). A putative androgen receptor $\left(K_{\mathrm{d}}\right.$ : $10^{-10} \mathrm{~mol} \mathrm{1}^{-1} ; 3-9 \mathrm{fmol} \mathrm{g}^{-1}$ tissue) was found mainly in the nuclei of testicular cells when actively undergoing spermatogenesis. This suggests that, as in higher vertebrates, testosterone is implicated in spermatogenetic step regulation (meiosis and spermiogenesis) in lizard testis. In the cytosol, testosterone-binding molecules $\left(K_{\mathrm{d}}\right.$ : $10^{-9} \mathrm{~mol} \mathrm{1}^{-1} ; 384-784 \mathrm{fmol}^{-1}$ tissue) with several properties of androgen-binding proteins are present from autumn to spring. The behaviour of these molecules is consistent with the role assigned to androgen-binding proteins as androgen reservoir.

A putative oestrogen receptor is present throughout the sexual cycle, except during the culmination phase (breeding). The putative oestrogen receptor may be involved in the regulation of the first spermatogenetic step (spermatogonia multiplication) and in the induction of post-reproductive refractoriness. This phase is present in temperatezone lizards.

These studies show that the evaluation of sex-steroid-binding molecules is useful in considering the relationships between sex hormones and spermatogenetic activity in the testes of lizards.
\end{abstract}

Keywords: sex-steroid-binding molecules; testis; reproductive cycle; lizard

\section{Introduction}

In the lizard Podarcis sicula sicula, as in many lizards inhabiting temperate zones, the sexual cycle is divided into well-defined stages (Licht et al., 1969; Angelini \& Picariello, 1975; Callard \& Ho, 1980; Licht, 1984; Lofts, 1987). Males show a discontinuous spermatogenetic cycle with two waves of sperm production: in autumn and early spring, although only the latter is of physiological relevance (prenuptial type; Saint Girons, 1963). In spring, as lizards leave winter shelters, gonads and secondary sexual characteristics start developing (regenerative phase). In the testis, Leydig cells become hypertrophic and secretory; in seminiferous tubules, after degeneration of the germ cells that developed in autumn (from spermatocytes), new sustained sperm production begins and lasts until June (culminative phase). In early summer, postnuptial refractoriness of the testis to environmental stimuli brings about a break in spermatogenesis (germ cells from spermatocytes degenerate), as well as regression of Leydig cells and secondary sexual characteristics. In the shrunken testis, seminiferous tubules include Sertoli cells, spermatogonia and a few spermatocytes; Leydig cells become indistinguishable from intertubular fibroblasts. In late summer and early autumn, as refractoriness vanishes, spermatogenesis is slowly resumed (autumn recrudescence), although it is not coupled with spermiation or development of Leydig cells and secondary sexual 
characteristics. From November until March, spermatogenesis is halted by low temperature (winter stasis); the lizards semi-hibernate (Della Corte et al., 1966; Botte \& Angelini, 1980; Angelini \& Ghiara, 1984; Angelini et al., 1986).

Plasma sex hormone profiles are related to sexual cycle phases. Testosterone concentration increases during spring when gonadal and secondary sexual characteristics recrudesce, and reaches peak values at the beginning of the culminative phase. In summer, an increase in oestradiol concentration in plasma coincides with the beginning of the regressive phase (Botte \& Angelini, 1980; Ciarcia et al., 1986; Andò et al., 1990).

However, concentrations of intratesticular sex hormones follow the spermatogenetic pattern and plasma sex hormone profiles only in part. Although significant testosterone concentrations are present in the active testis, the hormone concentration reaches its highest value in the inactive gonad (Andò et al., 1992). Moreover, significant oestradiol titres have been recorded in both active and inactive testes (Lupo di Prisco et al., 1967; Andò et al., 1992).

Since such reported data prevent an evaluation of the requirement for sex hormones for testicular activity, we attempted a different approach, i.e. the determination of distribution patterns of receptor and nonreceptor sex-steroid-binding molecules in the testis throughout the sexual cycle. As reported in several mammalian and nonmammalian species, the concentration of receptors is important for modulation of testicular activity (Callard \& Callard, 1987, for review; Mak \& Callard, 1987; Buzek \& Sanborn, 1988; Pasmanik \& Callard, 1988; Fasano et al., 1989; Singh \& Callard, 1989).

\section{Material and Methods}

\section{Animals and tissues}

Adult males of Podarcis sicula sicula were captured in the outskirts of Naples from October 1988 to July 1990 during the major phases of their reproductive cycle: i.e. autumn gonadal recrudescence (October), winter stasis (January), spring resumption of the genital apparatus (March), breeding period (May), postreproductive refractory period (July). Soon after capture, the lizards were rapidly anaesthetized by immersion in an ice bath. Blood was extracted for $5 \mathrm{~min}$ through a heparinized glass capillary inserted into the heart. Plasma, obtained after brief centrifugation $(800 \mathrm{~g}$ for $10 \mathrm{~min})$, was preserved in liquid nitrogen until use. At autopsy, testes were excised and weighed. A small piece of testis with the corresponding epididymis, from each animal, was placed in Bouin's fixative fluid. The remainder of the testes was frozen separately in liquid nitrogen and stored for steroid intratesticular assay and determinations of sex-hormone-binding molecules.

\section{Chemicals}

The hormones $\left[2,4,6,7,-{ }^{3} \mathrm{H}\right]$ oestradiol $\left(90 / 110 \mathrm{Ci} \mathrm{mmol} 1^{-1}\right)$ and $\left[1,2,6,7,{ }^{3} \mathrm{H}\right]$ testosterone $\left(80 / 105 \mathrm{Ci} \mathrm{mmol} 1^{-1}\right)$ were obtained from Amersham Radiochemical Centre (Amersham, Bucks, UK). Unlabelled steroids, DNA cellulose, Norit A charcoal, DNAse I (type V), collagenase (type V) and other pure-grade chemicals were purchased from Sigma Chemical Co. (St Louis, MO, USA). Dextran T-70 was purchased from Pharmacia Fine Chemicals (Piscataway, NJ, USA). Dulbecco's modified Eagle's medium (DMEM) was purchased from Gibco (Paisley, UK). Testosterone and oestradiol antisera were a gift from G. F. Bolelli, CNR Physiopathology of Reproduction Service, University of Bologna, Italy. Testosterone antiserum crossreacted $(>80 \%)$ with dihydrotestosterone. Maxifluor scintillation fluid was from Packard (Milan, Italy).

\section{Tissue preparation}

All operations were carried out at $4^{\circ} \mathrm{C}$. Minced tissues were weighed and homogenized in 2.5 volumes (wt/vol) of $10 \mathrm{mmol}$ Tris- $\mathrm{HCl}^{-1}, 1 \mathrm{mmol}$ EDTA $1^{-1}, 1 \mathrm{mmol} 2$-mercaptoethanol $\mathrm{l}^{-1}$ and $10 \%$ glycerol, $\mathrm{pH} 7 \cdot 8$ (TEMG), containing $0.05 \mathrm{~mol} \mathrm{NaCl}^{-1}$ (homogenization buffer). The suspension was centrifuged at $800 \mathrm{~g}$ for $10 \mathrm{~min}$. The recovered supernatant was centrifuged at $105000 \mathrm{~g}$ for $1 \mathrm{~h}$; the final supernatant constituted the cytosolic fraction.

The $800 \mathrm{~g}$ pellet was resuspended in four volumes of $10 \mathrm{mmol}$ Tris- $\mathrm{HCl} 1^{-1}$ buffer, $\mathrm{pH} 7 \cdot 5$, containing $3 \mathrm{mmol}$ $\mathrm{MgCl}_{2} 1^{-1}, 2 \mathrm{mmol}$ monothioglycerol $1^{-1}$ and $0.25 \mathrm{~mol}$ saccharose $1^{-1}$ (rinsing buffer), and centrifuged at $800 \mathrm{~g}$ for $10 \mathrm{~min}$. This operation was repeated twice. The final pellet was resuspended in 2.5 volumes (wt/vol) of TEMG containing $0.7 \mathrm{~mol} \mathrm{KCl} 1^{-1}$ (extraction buffer). The mixture was frozen and thawed, and left for $1 \mathrm{~h}$ in an ice bath, with continuous stirring; thereafter, it was centrifuged at $105000 \mathrm{~g}$ for $1 \mathrm{~h}$. The supernatant constituted the nuclear extract. 
Separation of seminiferous tubules from intertubular components was carried out in some testes. Fifteen gonads were decapsulated and plunged in seven volumes of DMEM containing $1 \mathrm{mg}$ collagenase $\mathrm{ml}^{-1}$. The mixture was incubated at room temperature for $15 \mathrm{~min}$ in a shaking waterbath $\left(120\right.$ cycles $\left.\mathrm{min}^{-1}\right)$ to dissociate seminiferous tubules that sedimented and were rescued after decanting the supernatant containing the intertubular components. Tubules were washed twice with $7 \mathrm{ml}$ of DMEM. From combined supernatants, intertubular components were pelleted by brief centrifugation at $800 \mathrm{~g}$ for $10 \mathrm{~min}$. The pellet was resuspended in homogenization buffer $1: 2 \cdot 5(\mathrm{vol} / \mathrm{vol})$ and used to make cytosol and nuclear fractions. Sedimented tubules were suspended in $7 \mathrm{ml}$ DMEM containing $0.05 \mathrm{mg}$ DNAse $\mathrm{ml}^{-1}$ and $1 \mathrm{mg}$ collagenase $\mathrm{ml}^{-1}$. The mixture was incubated for $1 \mathrm{~h}$ at room temperature in a shaking waterbath $\left(120\right.$ cycles $\left.\min ^{-1}\right)$ to eliminate peritubular components. The suspension was centrifuged, and pelleted tubules were suspended in homogenization buffer $1: 2.5(\mathrm{vol} / \mathrm{vol})$ and used to make cytosol and nuclear extract fractions.

\section{Measurement of labelled-steroid binding in cytosol and nuclear extracts}

Aliquots $(0.2 \mathrm{ml})$ of cytosol and nuclear extract were incubated with $5 \mathrm{nmol}$ labelled testosterone or oestradiol $\mathrm{l}^{-1}$, with or without a 100 -fold excess of unlabelled testosterone or oestradiol, respectively. After incubation for $16 \mathrm{~h}$ at $4^{\circ} \mathrm{C}, 0.6 \mathrm{ml}$ of TEMG, containing $0.05 \%(\mathrm{wt} / \mathrm{vol})$ dextran and $0.5 \%(\mathrm{wt} / \mathrm{vol})$ coated charcoal, was added. The mixture was vortexed and kept in an ice bath for $5 \mathrm{~min}$; thereafter, it was centrifuged at $800 \mathrm{~g}$ for $10 \mathrm{~min}$ at $4^{\circ} \mathrm{C}$. The supernatant $(0.8 \mathrm{ml})$ was transferred to a DNA cellulose column $\left(0.5 \times 6 \mathrm{~cm}^{2}\right)$ previously washed overnight with TEMG buffer containing $0.01 \mathrm{~mol} \mathrm{NaCl} 1^{-1}$ and $0.2 \%$ bovine serum albumin (BSA). The sample was loaded and the column was transferred for $45 \mathrm{~min}$ at $22^{\circ} \mathrm{C}$ and soon after for $15 \mathrm{~min}$ at $4^{\circ} \mathrm{C}$. The column was then washed with $10 \mathrm{vol}$ of TEMG containing $0.01 \mathrm{~mol} \mathrm{NaCl} \mathrm{I}^{-1}$ and $0.02 \% \mathrm{BSA} ; 12$ fractions (each of $0.5 \mathrm{ml}$ ) were collected. The adhering

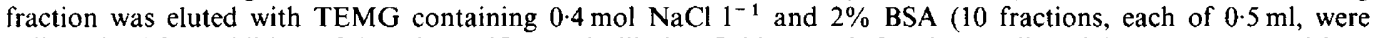
collected). After addition of $4.5 \mathrm{ml}$ Maxifluor scintillation fluid to each fraction, radioactivity was measured in a Packard spectrometer (Packard 1600-CA) at $45 \%$ efficiency counting.

For $K_{\mathrm{d}}$ determinations, $0.2 \mathrm{ml}$ aliquots of cytosol or nuclear extract were added to tubes containing increasing amounts $\left(0 \cdot 3\right.$ to $\left.5 \cdot 0 \mathrm{nmol}^{-1}\right)$ of labelled testosterone or oestradiol, with or without a 100 -fold excess of the respective unlabelled hormone. Incubation was carried out for $16 \mathrm{~h}$ at $4^{\circ} \mathrm{C}$. The bound and unbound steroids were separated by DNA cellulose. Specific binding data were analysed according to Scatchard's (1949) graphic method.

For binding specificity evaluation, $0.2 \mathrm{ml}$ of sample (as above) was added to $5 \mathrm{nmol}$ of labelled testosterone or oestradiol $1^{-1}$ with or without a 1000 -fold excess of various unlabelled steroids. Incubation and separation of bound and unbound steroids were performed as reported before.

For determination of dissociation kinetics, samples $(0.2 \mathrm{ml})$ of cytosol and nuclear extract were incubated for $16 \mathrm{~h}$ at $4^{\circ} \mathrm{C}$ with labelled testosterone. After incubation, a 100-fold excess of unlabelled testosterone was added to mixtures, and separation of bound from unbound hormones was performed by DNA cellulose for different times (0 to $180 \mathrm{~min}$ ).

\section{Extraction and determination of sex hormones}

Sex hormones were determined in testicular extracts and plasma using the radioimmunological assay for this species (Ciarcia et al., 1986).

Testicular extracts were prepared according to Andò et al. (1992). Frozen testes were disrupted in a Potter homogenizer. The resulting powder was taken up in four volumes of ethanol, vortexed and centrifuged. The supernatant was decanted whereas the residue was extracted again with four volumes of methanol; the combined supernantants were evaporated. The residue was dissolved in $1 \mathrm{ml}$ buffer and extracted twice with five volumes of ethyl ether. The ether extract was evaporated and the residue was used for sex steroid determinations.

In the radioimmunological assay, the following sensitivities were recorded: $3 \mathrm{pg}$ testosterone (intra-assay variation $5 \cdot 7 \%$, interassay variation $12 \%$ ); 3 pg oestradiol (intra-assay variation $5 \cdot 7 \%$, interassay variation $9 \%$ ).

\section{Protein determination}

Proteins were determined by the method of Lowry et al. (1951) using BSA as a standard.

\section{Statistical analysis}

Numerical data were analysed by a one-way ANOva followed by Duncan's multiple-range test.

\section{Results}

Testicular weight and plasma testosterone titres peaked in March $(P<0.01)$, at the onset of the breeding season (Table 1). Plasma oestradiol reached its highest concentration in July $(P<0.01)$ during the post-reproductive period. 
Table 1. Changes in testis weight and plasma and intragonadal titres of testosterone and oestradiol in male lizards (Podarcis sicula sicula) during the main phases of the sexual cycle

\begin{tabular}{|c|c|c|c|c|c|}
\hline \multirow[b]{2}{*}{ Period } & \multirow{2}{*}{$\begin{array}{l}\text { Testis weight } \\
\text { (mg) }\end{array}$} & \multicolumn{2}{|c|}{$\begin{array}{l}\text { Plasma hormones } \\
\left(\mathrm{ng} \mathrm{ml}^{-1}\right)\end{array}$} & \multicolumn{2}{|c|}{$\begin{array}{l}\text { Intragonadal hormones } \\
\text { (pg mg }{ }^{-1} \text { tissue) }\end{array}$} \\
\hline & & Testosterone & Oestradiol & Testosterone & Oestradiol \\
\hline $\begin{array}{l}\text { Recrudescence } \\
\text { (October) }\end{array}$ & $37 \cdot 0 \pm 1 \cdot 89^{*}$ & $9.7 \pm 0.9^{*}$ & $0.7 \pm 0.1^{*}$ & $115 \cdot 6 \pm 10 \cdot 1 \dagger$ & $18 \cdot 3 \pm 2 \cdot 3 \dagger$ \\
\hline $\begin{array}{l}\text { Winter stasis } \\
\text { (January) }\end{array}$ & $30 \cdot 3 \pm 2 \cdot 89$ & $26 \cdot 8 \pm 1 \cdot 7$ & $0 \cdot 2 \pm 0$ & $121 \cdot 8 \pm 11 \cdot 3$ & $17 \cdot 5 \pm 1 \cdot 8$ \\
\hline $\begin{array}{l}\text { Spring resumption } \\
\text { (March) } \\
\text { Breeding }\end{array}$ & $43 \cdot 5 \pm 3 \cdot 2$ & $210 \cdot 5 \pm 9 \cdot 5$ & $0 \cdot 3 \pm 0$ & $225 \cdot 4 \pm 17 \cdot 9$ & $16 \cdot 9 \pm 1 \cdot 3$ \\
\hline $\begin{array}{l}\text { (May) } \\
\text { Post-reproductive }\end{array}$ & $40 \cdot 6 \pm 3 \cdot 5$ & $148 \cdot 2 \pm 6 \cdot 4$ & $1 \cdot 1 \pm 0 \cdot 3$ & $227 \cdot 3 \pm 18 \cdot 2$ & $40 \cdot 7 \pm 3 \cdot 7$ \\
\hline (July) & $22 \cdot 1 \pm 4 \cdot 5$ & $8.4 \pm 1.8$ & $1.5 \pm 0.4$ & $281 \cdot 4 \pm 23 \cdot 4$ & $81 \cdot 6 \pm 8 \cdot 6$ \\
\hline
\end{tabular}

*Mean \pm SEM of ten determinations.

†Mean \pm SEM of three values.

Determinations of intragonadal sex hormones indicated progressive accumulation of testosterone from October to July, when a peak value was achieved $(P<0.01)$. Oestradiol intratesticular content increased during the reproductive and post-reproductive periods and peaked in July $(P<0 \cdot 01)$.

A typical distribution pattern of labelled testosterone- (Fig. 1a) or oestradiol- (Fig. 1b) binding molecules was obtained after separation by DNA cellulose columns.

A significant number of nonadhering labelled testosterone-binding molecules was present in the cytosol throughout the sexual cycle, although decreasing from October until July. Fewer of these molecules were obtained from the nuclear extract. Adhering labelled testosterone-binding molecules were recovered from cytosol in March, whereas they were present in nuclear extract when testes were engaged in active spermatogenesis (October, March and May) (Fig. 2a).

Nonadhering labelled oestradiol-binding molecules were present in both cytosol and nuclear extract, although their concentration was higher in the cytosol and they were absent in May in nuclear extract. Adhering labelled oestradiol-binding molecules were recovered from cytosol (October, March and July) and from nuclear extract (October, January, March and July). These molecules were absent from both cytosol and nuclear extracts in May (Fig. 2b).

Nonadhering, cytosolic, labelled, testosterone-binding molecules showed a lower affinity for the hormone than adhering molecules. Nonadhering, labelled, testosterone-binding molecules from nuclear extract were not saturable by the hormone and, therefore, their $K_{\mathrm{d}}$ value was not determined (Table 2). Values of $K_{\mathrm{d}}$, in different periods of the sexual cycle, did not show significant changes (not shown). Scatchard plots conducted on adhering labelled testosterone- and oestradiolbinding molecules from nuclear extract are reported (Fig. 3).

On labelled testosterone binding, oestradiol, progesterone and diethylstilbestrol significantly competed, although oestradiol and diethylstilbestrol competition was lower in cytosol nonadhering molecules, and progesterone competition was lower in nuclear extract nonadhering molecules (Table 3). Moreover, diethylstilbestrol did not compete with cytosol nonadhering molecules. Labelled oestradiol binding to nonadhering molecules in cytosol and nuclear extract was displaced by testosterone, progesterone and diethylstilbestrol; but testosterone and progesterone were less active when assayed on oestradiol-binding adhering molecules from cytosol and nuclear extracts.

Both adhering and nonadhering labelled testosterone-binding molecules were recovered from tubular and intertubular preparations (Fig. 4). Nonadhering testosterone-binding molecules were more abundant in the cytosol of intertubular preparations than were adhering molecules. Nonadhering cytosolic labelled oestradiol-binding molecules from intertubular and tubular preparations only were obtained in this experiment. 


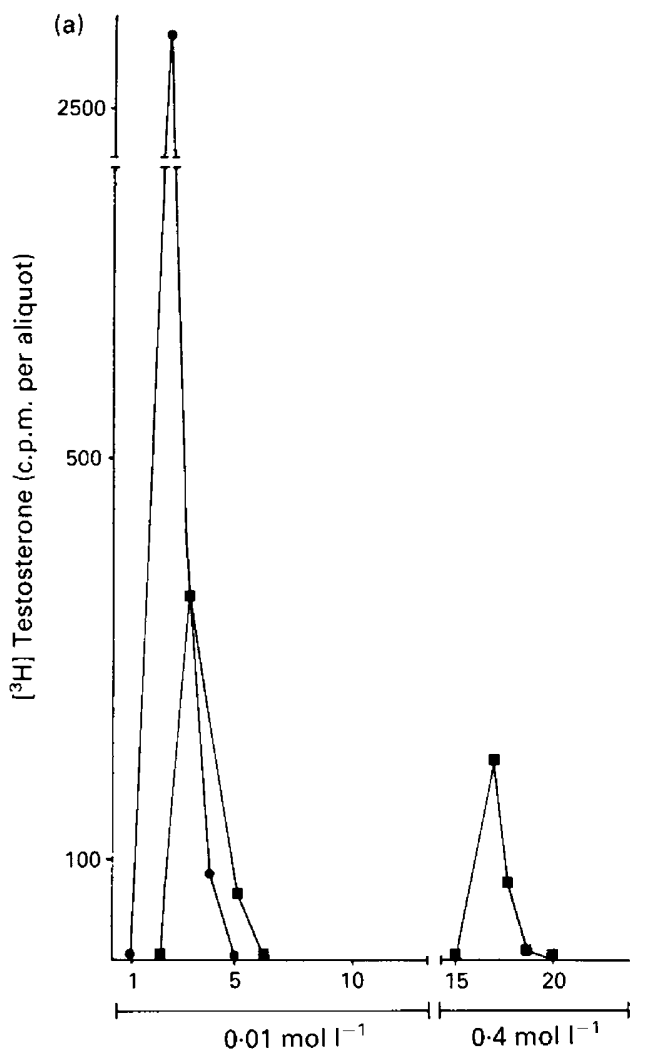

Fractions

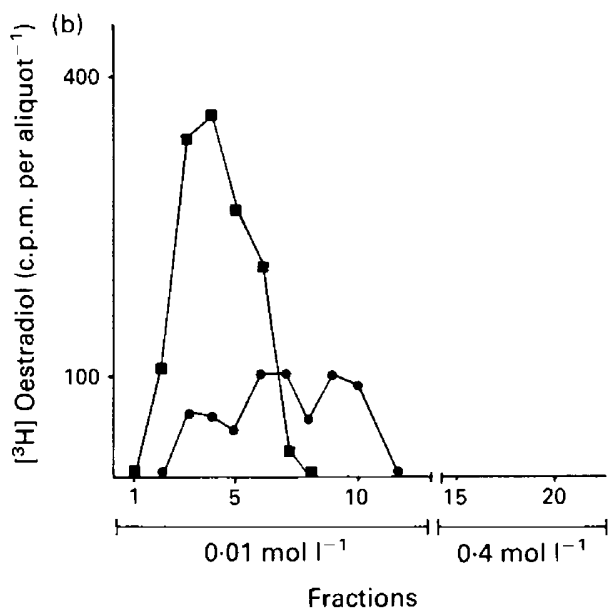

Fractions

Fig. 1. Typical distribution patterns of (a) labelled testosterone-binding and (b) oestradiolbinding molecules separated by DNA-cellulose column; $(\bullet)$ cytosol and ( $\mathbf{a})$ nuclear extract of testis of Podarcis sicula sicula during the breeding period.

In cytosol nonadhering fractions, two components were present, having half-life values of 10 and $40 \mathrm{~min}$, respectively (Fig. 5). Moreover, nuclear adhering molecules showed the highest half-life value $(52 \mathrm{~min})$.

\section{Discussion}

Steroid receptors and nonreceptor binding proteins have been identified in testes of several lower vertebrates (Callard \& Callard, 1987 for review). Although the presence of oestrogen receptors is well documented (Mak et al., 1982, 1983a, b; Callard \& Mak, 1985; Fasano et al., 1986, 1989; Ho et al., 1987), a testosterone receptor has been found only in goldfish testis (Pasmanik \& Callard, 1988). Nonreceptor steroid-binding proteins have been detected in the testis of Squalus acanthias (Mak \& Callard, 1987) and Necturus maculosus (Singh \& Callard, 1989).

In this study, we report the occurrence of testosterone and oestradiol receptors and of nonreceptor steroid-binding molecules in $P$. sicula sicula testis. These molecules, separated by DNA-cellulose affinity chromatography, undergo significant changes throughout the sexual cycle.

The putative androgen receptor has been detected in testicular nuclear extracts during periods of active spermatogenesis, i.e. in autumn and, in higher amounts, in spring. Only in the latter period is it present in the cytosol.The pattern of putative androgen receptor in the testis and its binding properties, high affinity $\left(K_{\mathrm{d}}=3 \cdot 1 \pm 1 \cdot 1-5.6 \pm 0.5 \times 10^{-10} \mathrm{~mol} 1^{-1}\right)$ and low capacity 


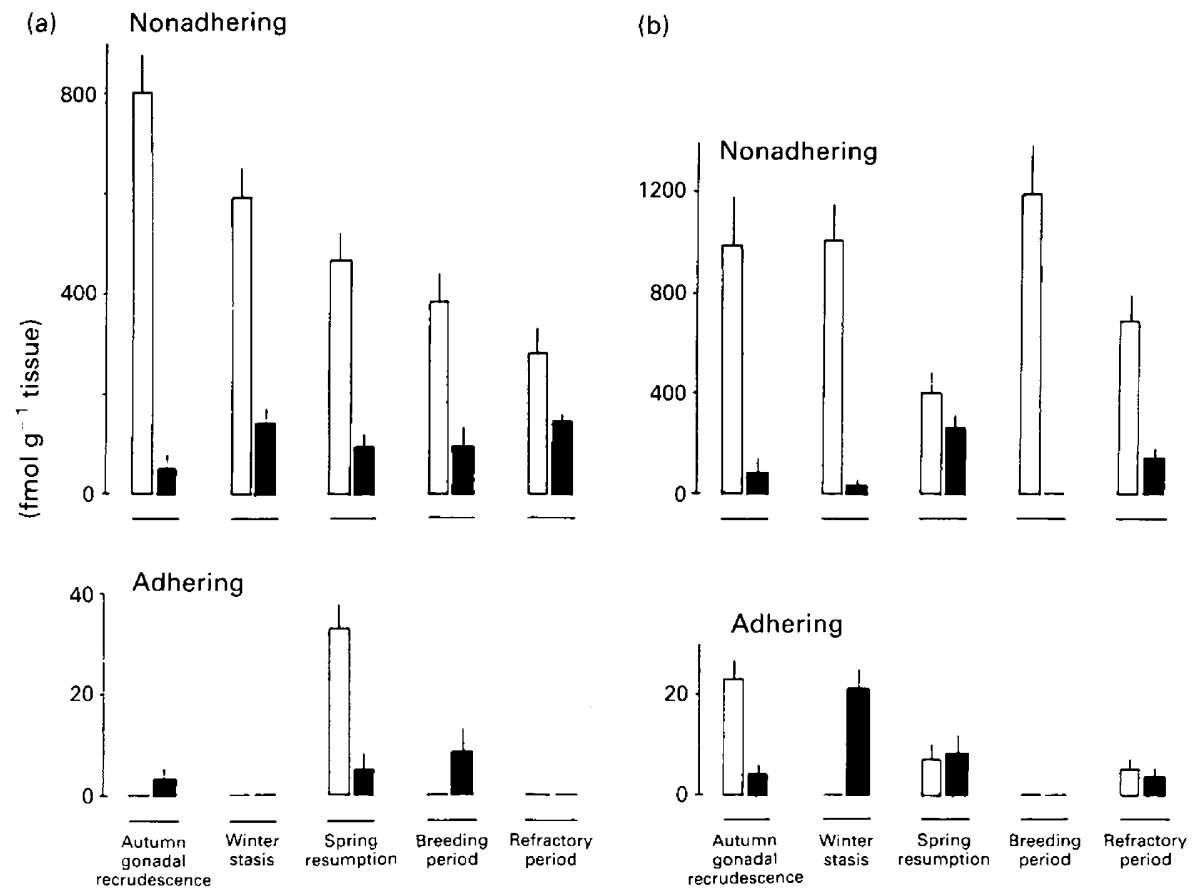

Fig. 2. DNA cellulose nonadhering and adhering labelled (a) testosterone-binding and (b) oestradiol-binding molecules of cytosol $(\square)$ and nuclear extract ( $\square$ ) of testis of the lizard Podarcis sicula sicula, during the sexual cycle.

Table 2. Values of $K_{\mathrm{d}}$ of adhering and nonadhering $\left[{ }^{3} \mathrm{H}\right]$ testosterone- and $\left[{ }^{3} \mathrm{H}\right]$ oestradiol-binding molecules prepared from cytosol and nuclear extracts of Podarcis sicula sicula testis, at the onset of the recovery phase

\begin{tabular}{|c|c|c|}
\hline & $\begin{array}{c}{\left[{ }^{3} \mathrm{H}\right] \text { testosterone }} \\
\text { DNA-adhering } \\
\left(\times 10^{-10} \mathrm{~mol}^{-1}\right)\end{array}$ & $\begin{array}{c}{\left[{ }^{3} \text { H]oestradiol }\right.} \\
\text { DNA-nonadhering }\end{array}$ \\
\hline $\begin{array}{l}{\left[{ }^{3} \mathrm{H}\right] \text { testosterone }} \\
\text { cytosol } \\
\text { nuclear extract }\end{array}$ & $\begin{array}{l}3 \cdot 1 \pm 1 \cdot 1^{*} \\
5 \cdot 6 \pm 0 \cdot 5\end{array}$ & $\begin{array}{c}6.3 \pm 0.1 \times 10^{-9} \mathrm{~mol} \mathrm{l}^{-1} \\
\dagger\end{array}$ \\
\hline $\begin{array}{l}{\left[{ }^{3} \mathrm{H}\right] \text { oestradiol }} \\
\quad \text { cytosol } \\
\text { nuclear extract }\end{array}$ & $\begin{array}{l}1 \cdot 0 \pm 0.6 \\
2 \cdot 8 \pm 1 \cdot 2\end{array}$ & $\begin{array}{l}3.0 \pm 0.8 \times 10^{-10} \mathrm{~mol}^{-1} \\
1.5 \pm 1.1 \times 10^{-10} \mathrm{~mol} \mathrm{l}^{-1}\end{array}$ \\
\hline
\end{tabular}

*Values are means of three separate experiments.

$\uparrow$ Not determined because of abnormal profile of Scatchard plot (see text).

$\left(12.6 \pm 20.4 \mathrm{fmol} \mathrm{g}^{-1}\right.$ tissue) for ligand and binding half-life of $52 \mathrm{~min}$ at $4{ }^{\circ} \mathrm{C}$, support its true receptor nature despite its broad specificity (testosterone binding is displaced by progesterone, oestradiol and diethylstilbestrol).

It has been suggested that, in reptiles, testosterone controls spermatogenesis (Lofts \& Chu, 1968), but this activity needs to be defined. In mammals (Steinberger, 1971, 1976; Lostroh, 1975) and amphibians (Rastogi \& Iela, 1980), testosterone is known to intervene in germ-cell meiosis and maturation. In $P$. sicula sicula, intragonadal testosterone concentrations agree only partially with this role, since the hormone reaches its higher titre in the testis in the postreproductive period 


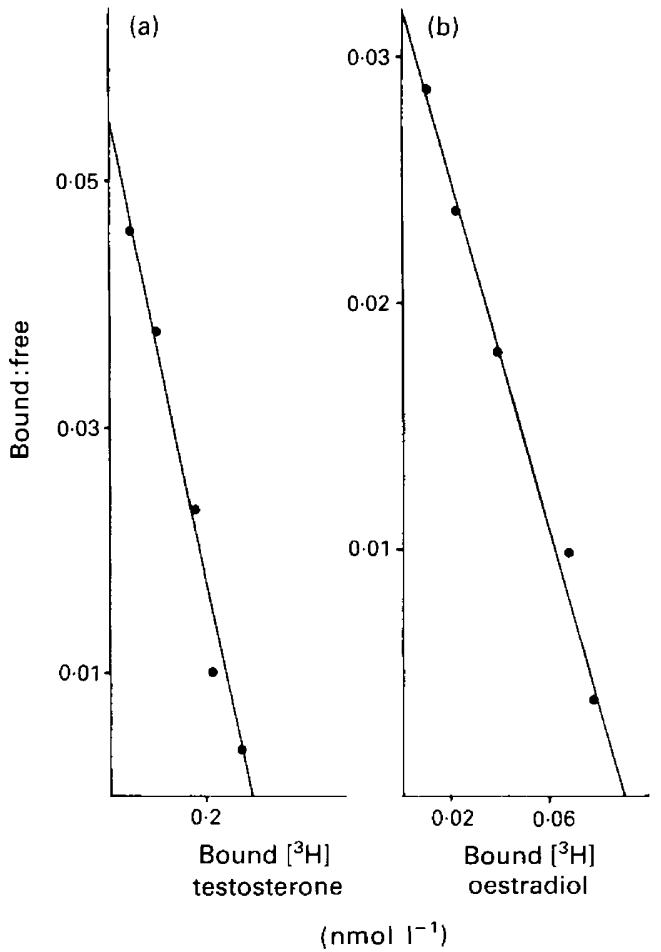

Fig. 3. Scatchard plot profiles of DNA-cellulose adhering labelled (a) testosterone- and (b) oestradiol-binding molecules of nuclear extract of testis of the lizard Podarcis sicula sicula, during spring resumption. $K_{\mathrm{d}}=5.4 \times 10^{-10} \mathrm{moll}^{-1}$ in (a) and $2.8 \times 10^{-10} \mathrm{moll}^{-1}$ in (b).

Table 3. Binding specificity of $\left[{ }^{3} \mathrm{H}\right]$ testosterone- and $\left[{ }^{3} \mathrm{H}\right]$ oestradiol-binding molecules obtained from cytosol and nuclear extract of Podarcis sicula sicula testis, at the onset of the recovery phase and separated on DNA-cellulose columns

\begin{tabular}{|c|c|c|c|c|}
\hline \multirow[b]{2}{*}{ Competitor } & \multicolumn{2}{|c|}{ DNA-nonadhering } & \multicolumn{2}{|c|}{ DNA-adhering } \\
\hline & Cytosol & Nuclear extract & Cytosol & Nuclear extract \\
\hline & \multicolumn{4}{|c|}{$\left[{ }^{3} \mathrm{H}\right]$ testosterone $\%$ of inhibition } \\
\hline Testosterone & 100 & 100 & 100 & 100 \\
\hline Oestradiol & 26 & 97 & 100 & 100 \\
\hline Progesterone & 88 & 68 & 100 & 100 \\
\hline \multirow[t]{2}{*}{ Diethylstilbestrol } & 26 & 94 & 0 & 94 \\
\hline & \multicolumn{4}{|c|}{$\left[{ }^{3} \mathrm{H}\right]$ oestradiol $\%$ of inhibition } \\
\hline Oestradiol & 100 & 100 & 100 & 100 \\
\hline Testosterone & 79 & 83 & 44 & 30 \\
\hline Progesterone & 84 & 100 & 45 & 36 \\
\hline Diethylstilbestrol & 67 & 86 & 68 & 87 \\
\hline
\end{tabular}

(Angelini et al., 1976; Andò et al., 1992). On the contrary, germ-cell meiosis and sperm production are better related to the number of androgen receptors, a change in which may assume a leading role in regulation of spermatogenesis. This suggestion is supported by the observation that, as in 


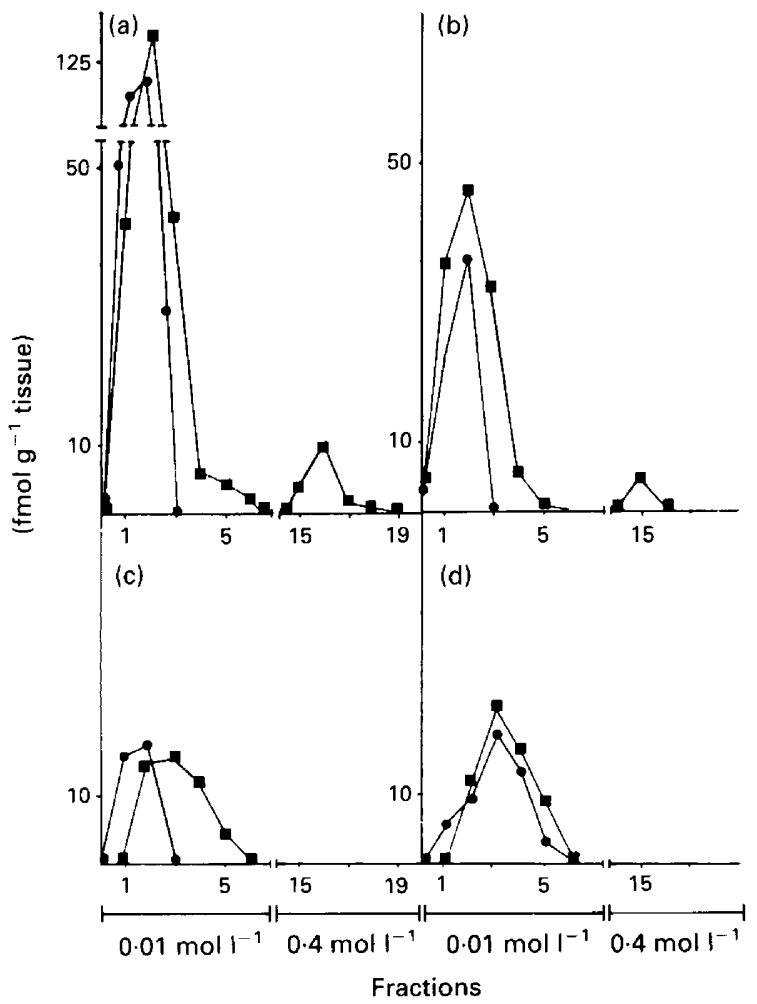

Fig. 4. DNA-cellulose separation pattern of labelled testosterone- (a and b) and oestradiol- (c and $d$ ) binding molecules from cytosol $(\boldsymbol{O})$ and nuclear extract $(\boldsymbol{a})$ of tubular (b and d) and intertubular ( $\mathrm{a}$ and $\mathrm{c}$ ) components of Podarcis sicula sicula testis, during the breeding period.

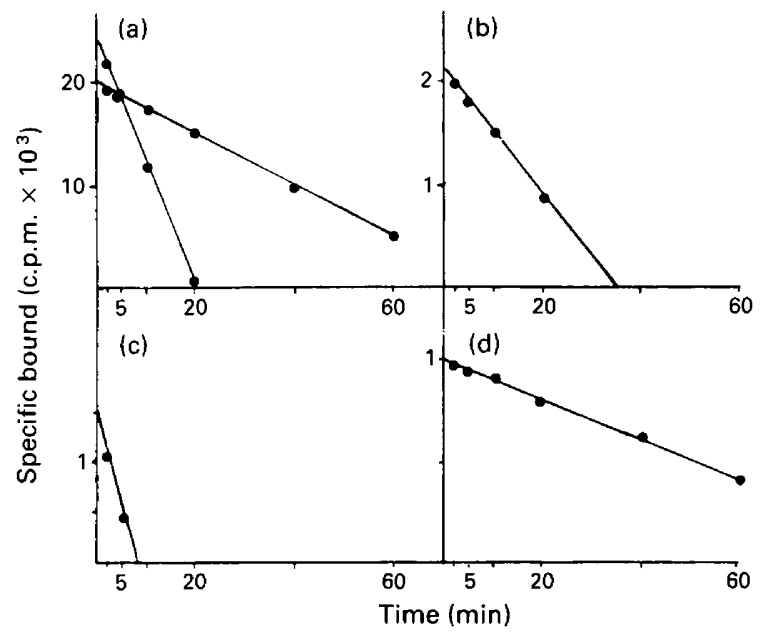

Fig. 5. Kinetic dissociation at $4^{\circ} \mathrm{C}$, of DNA-cellulose labelled testosterone-binding molecules in testis of the lizard Podarcis sicula sicula. Half-life was calculated as the time at which $50 \%$ binding was observed. Each value is the mean of duplicate determinations; (a) cytosol DNA nonadhering molecules, (b) cytosol DNA adhering molecules, (c) nuclear extract DNA nonadhering molecules and (d) nuclear extract DNA adhering molecules. 
rats (Buzek \& Sanborn, 1988), the intragonadal content of testosterone of $P$. sicula sicula testis is high enough to occupy all the available receptors. Changes in the concentration of receptors, therefore, might be a way of modulating the responsiveness of seminiferous tubule target cells to androgens (Buzek \& Sanborn, 1988).

In cytosol of lizard testis, nonreceptor testosterone-binding molecules have been found in high amounts (384-784 fmol $\mathrm{g}^{-1}$ of tissue). Their localization, ligand affinity $\left(K_{\mathrm{d}}=6 \cdot 3 \pm\right.$ $0 \cdot 1 \times 10^{-9} \mathrm{~mol}^{-1}$ ), broad specificity (the binding, besides testosterone, is displaced by progesterone and, at $26 \%$, by oestradiol) and half-life dissociation $\left(40 \mathrm{~min}\right.$ at $\left.4{ }^{\circ} \mathrm{C}\right)$ is reminiscent of several properties of vertebrate androgen-binding proteins (Bardin et al., 1981; Callard \& Callard, 1987 for a review). In lizards, the pool of putative androgen-binding proteins, however, seems to contain a second component with a very short half-life of dissociation $\left(10 \mathrm{~min}\right.$ at $\left.4^{\circ} \mathrm{C}\right)$. Androgen-binding protein functions are not well defined; it has been suggested that androgen-binding protein works as a testosterone reservoir to be used for spermatogenesis, and/or as a hormone carrier to target epididymal cells (Tindall et al., 1974; Danzo et al., 1977).

In the testis of mammals (Parvinen, 1982) and some lower vertebrates (Mak \& Callard, 1987), androgen-binding protein reaches its highest concentration immediately before spermiation. This finding is only in part consistent with the androgen-binding protein pattern in P. sicula sicula testis, since, although considerable concentrations of androgen-binding protein were found in the testis during the spermiation period (spring), the protein reached its maximum in October when sperm production rate was low and spermiation absent (Angelini et al., 1976). The androgen-binding protein pattern in lizards can be better correlated to androgen-binding protein profile in Necturus maculosus (Singh \& Callard, 1989). In this urodele, the androgen-binding protein content in the testis does not change much when spermatogenetic activity is at a peak or during the regressed stages.

In mammals and some lower vertebrates, androgen-binding protein is synthesized and secreted by Sertoli cells (Bardin et al., 1981; Callard \& Callard, 1987; Singh \& Callard, 1988, 1989). In $P$. sicula sicula testis, androgen-binding protein was localized in the intertubular and the tubular testicular compartments. This suggests androgen-binding protein synthesis also from Leydig cells, a finding consistent with that reported for $N$. maculosus testis (Singh \& Callard, 1989).

Nonreceptor putative androgen-binding molecules have also been recovered from nuclear extract. These molecules differ from androgen-binding proteins. They show a broad specificity, are unsaturable by ligand and have a short half-life of dissociation $\left(17 \mathrm{~min}\right.$ at $\left.4^{\circ} \mathrm{C}\right)$. Their nature is unknown.

In $P$. sicula sicula testis, a putative oestradiol receptor is present throughout the sexual cycle, except during the culmination phase (when full sperm production occurs). Although the putative oestradiol receptor shows high ligand affinity $\left(K_{\mathrm{d}}=1.0 \pm 0.6-2.8 \pm 1.2 \times 10^{-10} \mathrm{~mol}^{-1}\right)$ and low capacity $\left(10.6 \pm 12.4 \mathrm{fmol} \mathrm{g}^{-1}\right.$ tissue), its specificity is broader than that of the oestrogen receptor of other nonmammalian testicular tissues (Mak et al., 1983a, b; Fasano et al., 1986; Ho et al., 1987), since about $40 \%$ of the oestradiol-binding is displaced by testosterone and progesterone. No definite functions have been assigned to oestradiol and the oestradiol receptor in vertebrate testis. In the mudpuppy, Necturus maculosus, it has been suggested that oestrogen is involved in the demise of Leydig cells at the end of their cycle of differentiation (Mak et al., 1983a; Pudney et al., 1983). In testis of turtle, Chrysemis picta, oestrogen receptor concentration is highest when Leydig cells are regressing and just before the start of the next spermatogenesis cycle (Callard \& Callard, 1987). In $P$. sicula sicula testis, the oestradiol receptor could be related to oestradiol use in the first steps of spermatogenesis, as proposed for Squalus acanthias (Pudney \& Callard, 1984; Callard et al., 1985). In March, just before testicular resumption, significant concentrations of the oestradiol receptor (present data) and of oestradiol (Lupo di Prisco et al., 1967; Andò et al., 1992; present data) have been detected in the testis. In summer-inactive testes, however, the oestradiol receptor of lizard testis could perform a different role, since it may mediate oestradiol inhibition of testicular functions (Botte \& Delrio, 1967). A similar role has been proposed for the oestradiol receptor in the testis of Rana esculenta (Fasano et al., 1986). 
Testicular oestradiol receptor in $P$. sicula sicula could also intervene in the oestradiol effect on chiasma pattern during meiosis. In this lizard, in fact, both terminal and interstitial chiasmata occur: the former prevails in autumn and can be induced by oestradiol administration (Cobror et al., 1986). This aspect is consistent with oestradiol receptor pattern in the testis since its testicular concentration is higher in autumn when terminal chiasmata predominate in the spermatogenesis.

In cytosol and, to a lesser extent, in nuclear extract, nonreceptor oestradiol-binding molecules are present, but their pattern does not show any clear relation to the sexual cycle phases. These molecules have high affinity $\left(K_{\mathrm{d}}=1.5 \pm 1 \cdot 1-3.0 \pm 0.8 \times 10^{-10} \mathrm{~mol}^{-1}\right)$ and low capacity for their ligand, but broad specificity. No data are available to assign a role to these components.

In lizard testis, the occurrence of putative sex-hormone receptors in tubular and intertubular compartments suggests that they, as in mammals (Brinkman et al., 1972; Nakhla et al., 1984), are present in both Leydig and Sertoli cells.

Our preliminary study indicates that, in the testis of $P$. sicula sicula, the evaluation of the sexhormone-binding protein dynamics is valuable for determining the putative role of sex hormones in the regulation of gonadal activity.

This research was supported by a grant (40\% and 60\%) from MURST. We thank G. F. Bolelli (CNR, Physiopathology of Reproduction Service, University of Bologna, Italy) for supplying sex hormone antisera.

\section{References}

Andò, S., Panno, M.L., Ciarcia, G., Imbrogno, E., Buffone, M., Beraldi, E., Sisci, D., Angelini, F. \& Botte, V. (1990) Plasma sex hormone concentrations during the reproductive cycle in the male lizard, Podarcis s. sicula. Journal of Reproduction and Fertility 90, 353-360.

Andò, S., Ciarcia, G., Panno, M.L., Imbrogno, E., Tarantino, G., Buffone, M., Beraldi, E., Angelini, F. \& Botte, V. (1992) Sex steroids levels in the plasma and in testis during the reproductive cycle of lizard Podarcis s. sicula Raf. General and Comparative Endocrinology 85, 1-7.

Angelini, F. \& Ghiara, G. F. (1984) Reproductive modes and strategies in vertebrate evolution. Bollettino di Zoologia 51, 121--203.

Angelini, F. \& Picariello, O. (1975) The course of spermatogenesis in Reptilia. I. Classification of the type of spermatogenesis encountered in nature. Atti della Accademia di Scienze Fisiche e Matematiche, Napoli, serie 3, 9, 61-107.

Angelini, F., Picariello, O. \& Botte, V. (1976) Influence of photoperiod and temperature on the testicular activity of the lizard Lacerta s. sicula Raf. Bollettino di Zoologia 43, 111-123.

Angelini, F., Ciarcia, G. \& Botte, V. (1986) Ambient cues and sexual cycle in the lizard, Podarcis s. sicula Raf. In Endocrine Regulations as Adaptive Mechanisms to Environment, pp. 227-232. Eds I. Assenmacher \& J. Boissin. Editions CNRS, Paris.

Bardin, C.W., Musto, N., Gunsalus, G., Kotite, N., Chey, S-L.F. \& Bechei, R. (1981) Extracellular androgen binding protein. Annual Reviews of Physiology 43, $189-239$.

Botte, V. \& Angelini, F. (1980) Endocrine control of reproduction in reptiles: the refractory period. In Steroids and their Mechanisms of Action in Nonmammalian Vertebrates, pp. 201-212. Eds G. Delrio \& J. Brachet. Raven Press, New York.
Botte, V. \& Delrio, G. (1967) Effect of oestradiol $17 \beta$ on the distribution of $3 \beta$-hydroxysteroid dehydrogenase in the testis of Rana esculenta and Lacertas. sicula. General and Comparative Endocrinology 9, $110-115$.

Brinkmann, A.O., Mulder, E., Lamers-Stahlhofen, G.J.M., Mechielsen, M.J. \& van der Molen, W.J. (1972) An estradiol receptor in rat testis interstitial tissue. FEBS Letters 26, 301-305.

Buzek, S.W. \& Sanborn, B.N. (1988) Increase in testicular androgen receptor during sexual maturation in the rat. Biology of Reproduction 39, 39-49.

Callard, I.P. \& Callard, G.V. (1987) Sex steroid receptors and non-receptor binding proteins. In Hormones and Reproduction in Fishes, Amphibians and Reptiles, pp. 355-384. Eds D. O. Norris \& R. E. Jones. Plenum Press, New York.

Callard, I.P. \& Ho, S-M. (1980) Seasonal reproductive cycles in reptiles. Progress in Reproductive Biology $\mathbf{5}$, 5-38.

Callard, G. V. \& Mak, P. (1985) Exclusive nuclear location of estrogen receptors in Squalus testis. Proceedings of the National Academy of Sciences, USA 82, 1336-1340.

Callard, G.V., Pudney, J.A., Mak, P. \& Canik, J. (1985) Stage-dependent changes in steroidogenic enzymes and estrogen receptors during spermatogenesis in the testis of the dogfish, Squalus acanthias. Endocrinology 117, 1328-1335.

Ciarcia, G., Angelini, F., Polzonetti, A., Zerani, M. \& Botte, V. (1986) Hormones and reproduction in the lizard, Podarcis s. sicula. In Endocrine Regulations as Adaptive Mechanisms to Environment, pp. 227-232. Eds I. Assenmacher \& J. Boissin. Editions CNRS, Paris.

Cobror, O., Olmo, E., Odierna, G., Angelini, F. \& Ciarcia, G. (1986) Cyclic variation of chiasma 
frequency and distribution in Podarcis s. sicula (Reptilia: Lacertidae). Genetics 71, 31-37.

Danzo, B.J., Cooper, T.G. \& Orgebin-Crist, M.C. (1977) Androgen binding protein (ABP) in fluids collected from the rete testis and cauda epididymis of sexually mature and immature rabbits and observations on morphological changes in the epididymis following ligation of the ductuli efferentes. Biology of Reproduction 17, 64-77.

Della Corte F., Angelini, F. \& Cosenza, L. (1966) Azione dell'FSH di maiale su esemplari di Lacerta s. sicula Raf. con i testicoli in atrofia estiva. Atti della Società Peloritana 12,643-650.

Fasano, S., Pierantoni, R., Minucci, S., Di Matteo, L., Varriale, B. \& Chieffi, G. (1986) Presence of estrogen receptor in the frog, Rana esculenta. Trends in Life Sciences (India) 1(2), 141-144.

Fasano, S., Pierantoni, R., Minucci, S., Di Matteo, L. \& Chieffi, G. (1989) Seasonal fluctuations of estrogen binding activity in the testis of the frog, Rana esculenta. General and Comparative Endocrinology $75,157-161$.

Ho, S-M., Press, D., Liang, L-C. \& Sower, S. (1987) Identification of an estrogen receptor in the testis of the sea lamprey, Petromyzon marinus. General and Comparative Endocrinology 67, 119-125.

Licht, P. (1984) Reptiles. In Marshall's Physiology of Reproduction, pp. 206-282. Ed. G. E. Lamming. Churchill Livingstone, London.

Licht, P., Hoyer, H.E. \& Van Oordt, G.P.V.J. (1969) Influence of photoperiod and temperature on testicular recrudescence and body growth in the lizards Lacerta sicula and Lacerta muralis. Journal of the Zoological Society of London 157, 469-501.

Lofts, B. (1987) Testicular function. In Hormones and Reproduction in Fishes, Amphibians, and Reptiles, pp. 283-325. Eds D. O. Norris \& R. E. Jones. Plenum Press, New York.

Lofts, B. \& Chu, K.W. (1968) Androgens and reptilian spermatogenesis. Archives d'Anatomie d'Histologie et d'Embryologie 51, 409-418.

Lostroh, A.J. (1975) Hormonal control of spermatogenesis. In Regulatory Mechanisms of Male Reproductive Physiology, pp. 13-23. Eds C. H. Spilman, T. J. Lobl \& K. T. Kirton. Excerpta Medica, Amsterdam.

Lowry, O.H., Roseborough, N.J., Farr, A.L. \& Randall, R.J. (1951) Protein measurement with the folin phenol reagent. Journal of Biological Chemistry 193, 265-279.

Lupo di Prisco, C., Chieffi, G. \& Delrio, G. (1967) Identification of steroid hormones from Lacerta sicula testes. Experientia 23, 73-74.

Mak, P. \& Callard, G.V. (1987) A novel steroid-binding protein in the testis of the dogfish Squalus acanthias. General and Comparative Endocrinology 68, 104-112.

Mak, P., Ho, S-M. \& Callard, I.P. (1982) Estrogen receptors in the turtle brain. Brain Research 231, 63-74.
Mak, P., Callard, I.P. \& Callard, G.V. (1983a) Characterization of an estrogen receptor in the testis of the urodele amphibian Necturus maculosus. Biology of Reproduction 28, 261-270.

Mak, P., Ho, S-M. \& Callard, I.P. (1983b) Characterization of an estrogen receptor in the turtle testis. General and Comparative Endocrinology 52, 182-189.

Nakhla, A.M., Matshu, J.P., Janne, O.A. \& Bardin, C.W. (1984) Estrogen and androgen receptors in Sertoli, Leydig, myoid and epithelial cells: effects of time in culture and cell density. Endocrinology 115, $121-128$.

Parvinen, M. (1982) Regulation of the seminiferous epithelium. Endocrinological Reviews 3, 404-417.

Pasmanik, M. \& Callard, G.V. (1988) A high abundance androgen receptor in goldfish brain: characteristics and seasonal changes. Endocrinology 123, 1162-1171.

Pudney, J. \& Callard, G.V. (1984) Identification of Leydig-like cells in the testis of the dogfish Squalus acanthias. Anatomy Records 209, 323-330.

Pudney, J., Canick, J.A., Mak, P. \& Callard, G.V. (1983) The differentiation of Leydig cells, steroidogenesis, and the spermatogenetic wave in the testis of Necturus maculosus. General and Comparative Endocrinology 50, 43-66.

Rastogi, R.K. \& Iela, L. (1980) Steroidogenesis and Spermatogenesis in anuran amphibia: a brief survey. In Steroids and their Mechanisms of Action in Nonmammalian Vertebrates, pp. 131-146. Eds G. Delrio \& J. Brachet. Raven Press, New York.

Saint Girons, H. (1963) Spermatogenese et evolution cyclique des caractères sexuels secondaires chez les Squamata. Annales des Sciences Naturelles. Zoologie, Paris 5, 461-478.

Scatchard, G. (1949) The attractions of proteins for small molecules and ions. Annals of the New York Academy of Sciences 51, 660-672.

Singh, S. \& Callard, G.V. (1988) Characteristics and zonal distribution of an androgen receptor in Necturus testis. American Society of Zoology 28, $158 \mathrm{~A}$.

Singh, S. \& Callard, G.V. (1989) A specific androgen binding protein (ABP) in Necturus testis and its zonal distribution. Journal of Experimental Zoology 250, 73-81.

Steinberger, E. (1971) Hormonal control of mammalian spermatogenesis. Physiological Reviews 51, 1-22.

Steinberger, E. (1976) Biological actions of gonadotropins in the male. Pharmacology Therapy 2, 771-786.

Tindall, D.J., Hansson, D., Sar, M., Stumpf, W., French, F.S. \& Neyfeh, S.N. (1974) Further studies on nuclear uptake and binding of androgen in rat epididymis. Endocrinology 95, 1119-1128.

Received 5 August 1991 